Old Dominion University

ODU Digital Commons

OEAS Faculty Publications

Ocean, Earth \& Atmospheric Sciences

2001

\title{
Holocene Sediment Records From the Continental Shelf of Mac. Robertson Land, East Antarctica
}

Peter N. Sedwick

Old Dominion University, Psedwick@odu.edu

Peter T. Harris

Lisette G. Robertson

Gary M. McMurtry

Maximilian D. Cremer

See next page for additional authors

Follow this and additional works at: https://digitalcommons.odu.edu/oeas_fac_pubs

Part of the Biogeochemistry Commons, Marine Biology Commons, Oceanography Commons, and the Paleontology Commons

\section{Repository Citation}

Sedwick, Peter N.; Harris, Peter T.; Robertson, Lisette G.; McMurtry, Gary M.; Cremer, Maximilian D.; and Robinson, Philip,

"Holocene Sediment Records From the Continental Shelf of Mac. Robertson Land, East Antarctica" (2001). OEAS Faculty

Publications. 106.

https://digitalcommons.odu.edu/oeas_fac_pubs/106

\section{Original Publication Citation}

Sedwick, P.N., Harris, P.T., Robertson, L.G., McMurtry, G.M., Cremer, M.D., \& Robinson, P. (2001). Holocene sediment records from the continental shelf of Mac. Robertson Land, East Antarctica. Paleoceanography, 16(2), 212-225. doi: 10.1029/2000pa000504 
Authors

Peter N. Sedwick, Peter T. Harris, Lisette G. Robertson, Gary M. McMurtry, Maximilian D. Cremer, and Philip Robinson 


\title{
Holocene sediment records from the continental shelf of Mac. Robertson Land, East Antarctica
}

\author{
Peter N. Sedwick, ${ }^{1}$ Peter T. Harris, ${ }^{1,2}$ Lisette G. Robertson, ${ }^{1}$ Gary M. McMurtry, ${ }^{3}$ \\ Maximilian D. Cremer, ${ }^{3}$ and Philip Robinson 4
}

\begin{abstract}
Geochemical records are presented for five sediment cores from basins on the continental shelf of Mac. Robertson Land, East Antarctica. The cores contain 2-4 m thick sequences of hemipelagic, siliceous mud and ooze (SMO) deposited under seasonally open marine conditions. The inner and middle shelf SMO sequences are massive dark olive green material, whereas the outer shelf SMO sequences are dark olive material interspersed with light olive green layers $\sim 1-10 \mathrm{~cm}$ thick. The biogenic material is dominated by marine diatoms including Fragilariopsis curta, Fragilariopsis cylindrus, and Chaetoceros spp. in the dark-colored SMO and Corethron criophilum in the light-colored layers. Radiocarbon dates suggest that the cores provide continuous accumulation records extending from $<1 \mathrm{kyr}$ before present (B.P.) back as far as 4-15 kyr B.P., with estimated accumulation rates of 0.07-5 $\mathrm{mm} \mathrm{yr}^{-1}$. The three core records from the middle and outer shelf suggest six episodes of increased accumulation of biogenic material at $\sim 5.5 \mathrm{kyr}$ B.P. (all three cores), 1, 2, and $6.2 \mathrm{kyr}$ B.P. (two of the three cores), and 3.8 and $10.8 \mathrm{kyr}$ B.P. (one core), most of which coincide with Corethron layers. We interpret these features as the result of enhanced diatom production over the outer shelf, possibly related to climatic warm periods. The absence of such features in the inner shelf core records is thought to reflect a relatively constant level of seasonal diatom production in adjacent waters maintained by a coastal polynya.
\end{abstract}

\section{Introduction}

The Antarctic continental shelf accounts for a significant fraction of Southern Ocean primary production and is a major area of oceanic deepwater formation [Comiso et al., 1993; Arrigo et al., 1998a; Deacon, 1984; Orsi et al., 1999]. Algal production in Antarctic shelf waters may thus play a significant role in the biogeochemical cycles of carbon and silicon, and in defining the composition of oceanic bottom waters [Smith and Gordon, 1997; Nelson et al., 1996; Arrigo et al., 1999]. At present, little is known about algal production and its relationship to environmental conditions on the Antarctic shelf during the late Quaternary. This largely reflects the dynamic nature of this continental margin, where seafloor sediments are widely reworked and redistributed by the action of ice and currents [Dunbar et al., 1985; Anderson and Molnia, 1989; Harris and O'Brien, 1996; Anderson, 1999]. However, some fjords and shelf basins provide natural sediment traps, where there are accumulations of hemipelagic sediments derived from overlying waters and adjacent shelf areas [Domack, 1982; Domack and McClennen, 1996; Harris and O'Brien, 1996; Barker et al., 1998; Harris and $O^{\prime} B$ rien, 1998]. A number of studies have made use of sediment cores from such locations to infer paleoenvironmen-

\footnotetext{
${ }^{1}$ Antarctic CRC, Hobart, Tasmania, Australia.

${ }^{2}$ Australian Geological Survey Organization, Hobart, Tasmania, Australia.

${ }^{3}$ Department of Oceanography, University of Hawaii, Honolulu, Hawaii.

${ }^{4}$ Department of Geology, University of Tasmania, Hobart, Tasmania, Australia.

Copyright 2001 by the American Geophysical Union.
}

Paper number 2000PA000504.

0883-8305/01/2000PA000504\$12.00 tal conditions on the Antarctic shelf during the Holocene and late Pleistocene [e.g., Leventer and Dunbar, 1988; Domack et al., 1993; Leventer et al., 1993, 1996; Shevenell et al., 1996; Frignani et al., 1998; Sedwick et al., 1998; Cunningham et al., 1999; Domack and Mayewski, 1999; Domack et al., 1999].

In these investigations, down core chemical, physical, and micropaleontological data together with radiocarbon chronologies have been used to construct regional records of the relative accumulation of biogenic versus lithogenic material, from which paleoenvironmental conditions have been inferred. A midHolocene climatic warming has been postulated on the basis of sediment records from the continental shelf of George $V$ and Adélie Land, Prydz Bay, and the western Ross Sea [Domack et al., 1991; Jacobson, 1997; Frignani et al., 1998; Cunningham et al., 1999], whereas sediments from the western margin of the Antarctic Peninsula and the continental shelf of Mac. Robertson Land contain evidence of century- to millennium-scale variations in accumulation of biogenic matter during the Holocene [Domack et al., 1993; Domack and Mayewski, 1999; Leventer et al., 1996; Sedwick et al., 1998]. Such changes have also been inferred from a high-resolution Ocean Drilling Program sediment record from the Palmer Deep on the Antarctic Peninsula, which contains evidence of $\sim 400,200$, and 50-70 year cycles in accumulation of pelagic biogenic material as well as longer-term paleoenvironmental changes, including a late Holocene neoglacial period, a mid-Holocene climatic optimum, an early Holocene climatic cooling, and a late Pleistocene deglacial episode [Domack et al., 2001].

These results naturally raise questions concerning the regional coherence of such records and the spatial scale of the inferred paleoenvironmental variations, given that present-day environmental conditions on the Antarctic margin, such as sea ice cover and algal biomass, are known to be highly variable [Comiso et al., 1993; Arrigo et al., 1998b; Barker et al., 1998; Parkinson, 1998]. Such questions can only be addressed by examining the 
coherence of paleoenvironmental records from the Antarctic shelf over a wide range of spatial scales. Here we present geochemical and sedimentological records for five sediment cores collected from shelf basins on the continental margin of Mac. Robertson Land, East Antarctica (the Mac. Robertson Shelf), a region which sustains relatively high algal biomass [Comiso et al., 1993] and may be a significant source of Antarctic Bottom Water [Orsi et al., 1999]. Preliminary analyses of two of these cores indicated significant differences in the sedimentary records from the inner and outer shelf over distances of $<100 \mathrm{~km}$ [Sedwick et al., 1998]. The new data presented here indicate that there have indeed been significant small-scale regional variations in the accumulation of biogenic material in the Mac. Robertson Shelf basins during the Holocene, but our results also provide evidence for millennialscale environmental variations in common with sedimentary records from other parts of the Antarctic margin.

\section{Materials and Methods}

\subsection{Study Area}

The Mac. Robertson Shelf extends some $400 \mathrm{~km}$ west of Prydz Bay, East Antarctica, with a typical width of $90 \mathrm{~km}$ (Figure 1). Here the continental shelf is made up of relatively shallow banks $<200 \mathrm{~m}$ in depth, separated by steep-sided basins and valleys up to $1200 \mathrm{~m}$ in depth which are interpreted as relict glacial troughs [O'Brien, et al., 1994; Harris and O'Brien, 1998]. Dense, highsalinity shelf water forms along the shelf in association with coastal polynyas, and this water sinks and flows off the shelf, probably filling the perched basins [Baines and Condie, 1998; Harris and O'Brien, 1998; Harris, 2000]. On the outer shelf and upper continental slope a large-scale westward flowing current follows the Antarctic Slope Front, extending from the surface waters to the seafloor, where current speeds up to several meters per second have been measured [Smith et al., 1984; Harris and O'Brien, 1998; Bindoff et al., 2000]. Coarse-grained sand and gravel deposits occur on the shallower areas of the outer shelf and upper slope, whereas finer-grained muds occur in the deep basins, particularly on the inner shelf [Harris and O'Brien, 1996, 1998]. These basins contain up to several meters (at least) of siliceous mud and ooze (SMO) deposited under seasonally open marine conditions, overlying sandy silt and glacial marine muds that were probably deposited under or near a permanent ice shelf [Harris and O'Brien, 1998; Anderson, 1999]. The radiocarbon ages of these facies in sediment cores from the Mac. Robertson shelf suggest that seasonally open marine conditions commenced around 10-12 kyr before present (B.P.) on the outer shelf and around $6 \mathrm{kyr}$ B.P. on the inner shelf, the difference representing the period over which a permanent ice canopy retreated across the continental shelf during the early Holocene [Harris and O'Brien, 1998; Sedwick et al., 1998].

\subsection{Sample Materials}

The sediment cores used in this study were collected from the Nielsen Basin (maximum water depth $\sim 1200 \mathrm{~m}$ ) and Iceberg Alley (maximum water depth $\sim 500 \mathrm{~m}$ ), which are two of the larger basins on the Mac. Robertson Shelf (Figure 1). The $9 \mathrm{~cm}$ diameter gravity cores were collected during cruises of RSV Aurora Australis in 1993, 1995, and 1997. Five cores were examined in this study (approximate water depths in parentheses): AA186-GC34 (470 m) and KROCK-GC1 (478 m) from the outer shelf in Iceberg Alley, AA149-GC2 (1100 m) and KROCK-GC2 $(1090 \mathrm{~m})$ from the inner shelf in the Nielsen Basin, and AA149-GC12 (626 m) from midshelf in the Nielsen Basin (Figure 1). These sites are separated by distances ranging from $\sim 5$ to $100 \mathrm{~km}$. All of the cores contain continuous sequences of SMO ranging in thickness from 267 to $374 \mathrm{~cm}$ (Figure 2). In cores KROCK-GC2 and AA149-GC12 the SMO units overlie sandy glacial marine muds. The SMO sequences are primarily a mixture of diatom ooze, fine-sand to coarse-silt quartz, and other fine lithogenic material. The SMO units of the

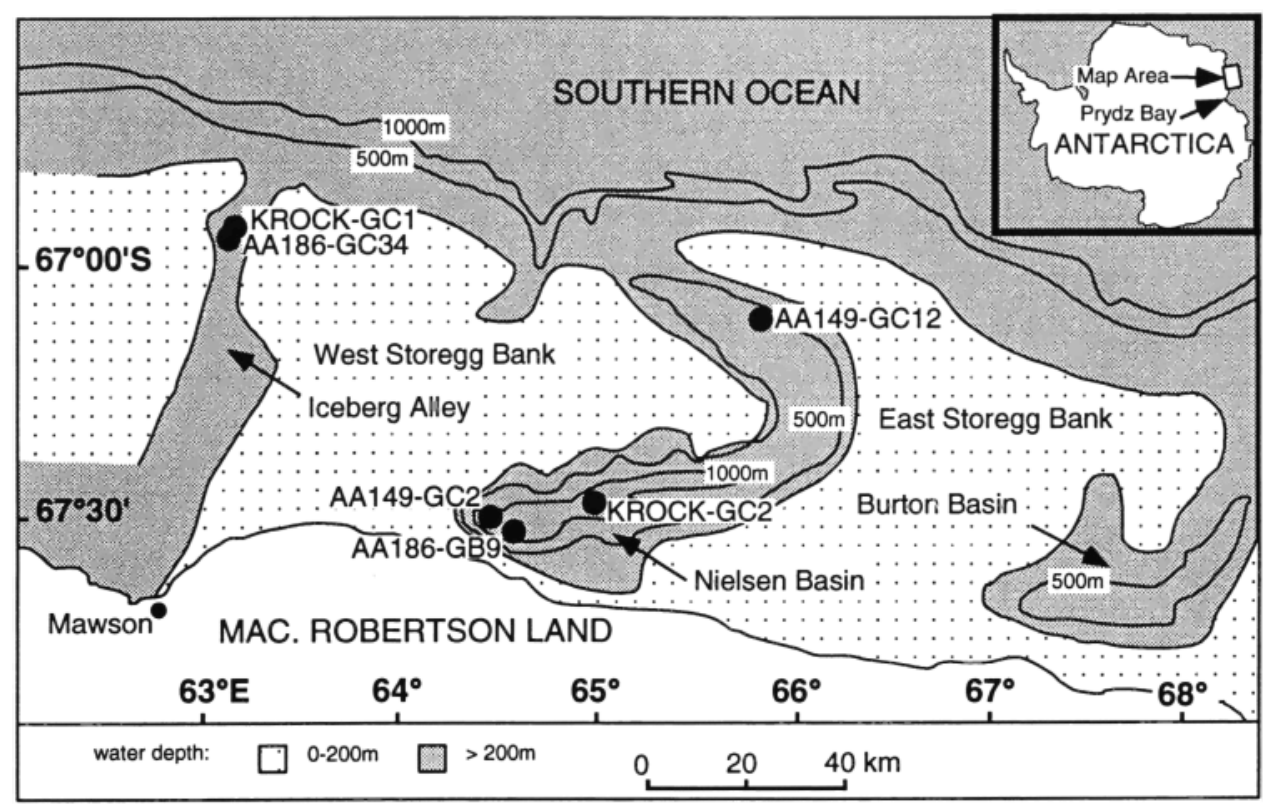

Figure 1. Map of the Mac. Robertson Shelf, showing sediment collection sites. 

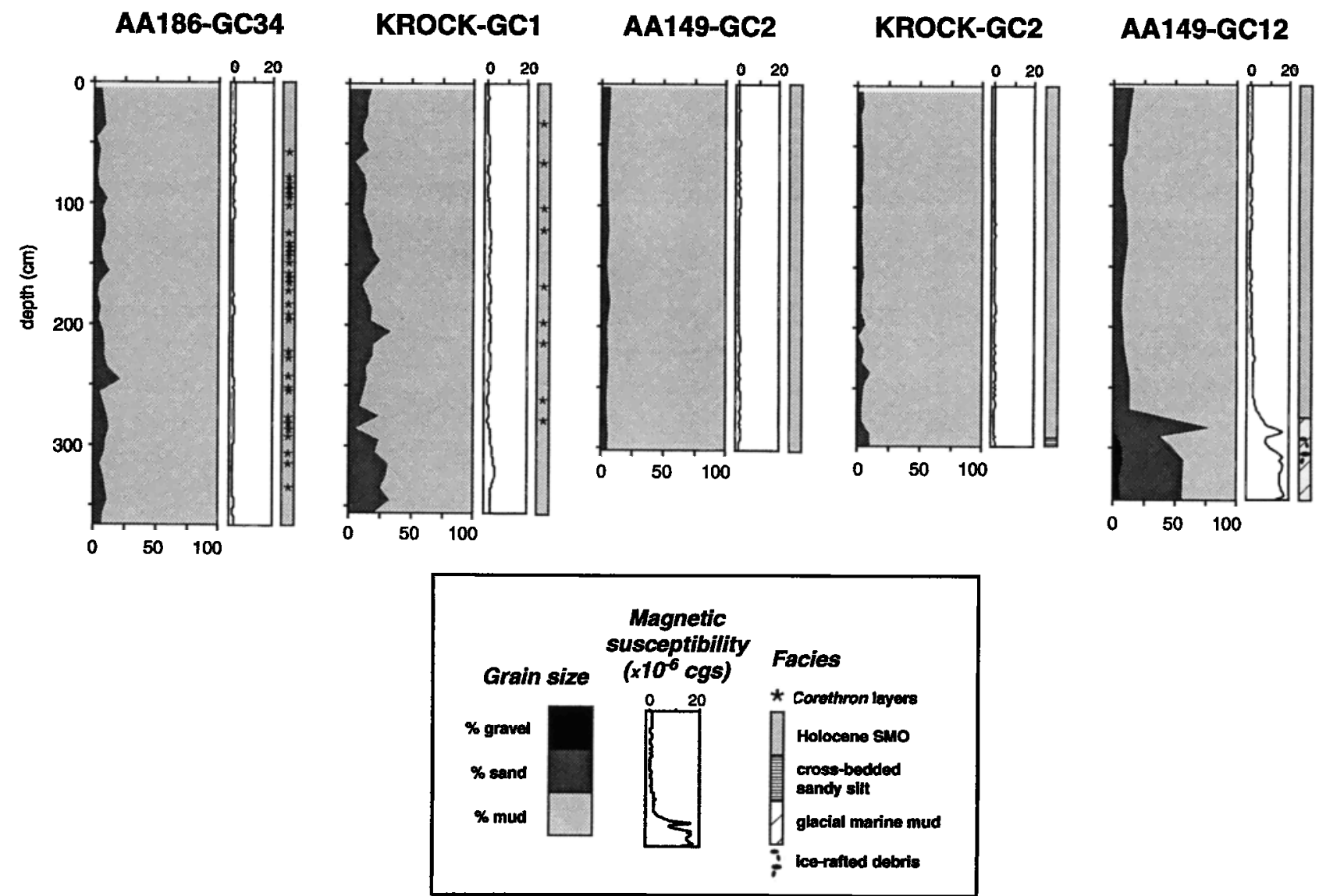

Figure 2. Grain size, magnetic susceptibility and facies classification for cores in this study.

inner and middle shelf cores (AA149-GC2, KROCK-GC2, and AA149-GC12) are massive, generally featureless, dark olive green sediment, whereas the SMO units from the outer shelf cores (AA186-GC34 and KROCK-GC1) are dark olive green material interspersed with fluffy, light olive green bands, which range in thickness from $\sim 1$ to $10 \mathrm{~cm}$. Finer-scale light and dark laminations were apparent in cores AA186-GC34 and KROCKGC1 when they were first split, but these features faded after several weeks of storage.

The cores were split and described immediately after collection, then wrapped in polyethylene and stored at $2^{\circ} \mathrm{C}$. The cores were subsampled for various chemical and physical measurements in Hobart. Subsamples were taken over $10 \mathrm{~cm}$ intervals for geochemical analysis, and the geochemical data presented in section 3.2 represent the depth-averaged bulk compositions of these $10 \mathrm{~cm}$ thick subsamples. In addition, 1-2 cm thick subsamples were taken from selected depths for radiocarbon dating and grain-size analysis, $1 \mathrm{~cm}$ thick subsamples were taken from the upper $5-10 \mathrm{~cm}$ of the cores for gamma spectrometric analysis, and $1 \mathrm{~cm}^{3}$ subsamples were taken at $10 \mathrm{~cm}$ intervals for determination of dry bulk density. The uppermost portions of the outer shelf cores suffered some compaction $(<10$ $\mathrm{cm}$ ) and minor stratigraphic disturbance after collection owing to the high water content of the sediment, but we have made no attempt to correct our data for these effects. In addition, the uppermost section of core KROCK-GCl shrank in length from
100 to $\sim 90 \mathrm{~cm}$ prior to subsampling owing to water loss during storage. In the presentation of data for this core, average sample depths between 0 and $90 \mathrm{~cm}$ have been multiplied by a factor of $100 / 90$ in an effort to correct for this shrinkage.

\subsection{Core Chronology and Isotopic Analyses}

The near absence of carbonate microfossils in the cores precludes use of standard $\delta^{18} \mathrm{O}$ stratigraphy and/or radiocarbon dating of calcium carbonate, whereas the likelihood of nonuniform sedimentation rates and the presence of significant concentrations of authigenic uranium (see section 3.2) precludes the estimation of accumulation rates using the uranium series radionuclides ${ }^{226} \mathrm{Ra},{ }^{230} \mathrm{Th}$, and ${ }^{231} \mathrm{~Pa}$. The primary chronostratigraphic tool we have used in this study is radiocarbon dating of bulk organic carbon (typically 1-2\% by mass in these sediments), which has been successfully employed in other studies of sediments from the Antarctic continental shelf [e.g., Domack et al., 1989; Leventer et al., 1996; Domack et al., 2001]. Radiocarbon ages were determined by accelerator mass spectrometry at either the Australian Nuclear Science and Technology Organization (ANSTO) or the New Zealand Institute of Geological and Nuclear Sciences (NZI). Radiocarbon dates are reported here as conventional radiocarbon years before present, as defined by Stuiver and Polach [1977]. The $\delta^{13} \mathrm{C}$ values used to calculate the radiocarbon ages were either measured (NZI analyses) or 
assumed (ANSTO analyses), with the assumed values based on $\delta^{13} \mathrm{C}$ measurements of subsamples from cores KROCK-GC1 and KROCK-GC2 performed by the Australian Geological Survey Organization. The errors introduced in the radiocarbon ages due to the use of assumed $\delta^{13} \mathrm{C}$ values are likely to be less than the anaiytical uncertainties in the ${ }^{14} \mathrm{C}$ measurements, given the range of measured $\delta^{13} \mathrm{C}$ values (-24.1 to $-34.1 \%$ ). In addition, unsupported ${ }^{210} \mathrm{~Pb}$ was determined in core top subsamples by gamma spectrometry [McMurtry et al., 1995] in an effort to evaluate the possible loss of core top material during sample collection.

\subsection{Physical and Geochemical Measurements}

Down core magnetic susceptibility, which provides a relative measure of ferromagnetic (i.e., lithogenic) mineral content [Leventer et al., 1996], was determined with a Bartington MS-2 magnetic susceptibility meter. The cores were also $\mathrm{X}$-rayed in order to identify macroscopic sedimentary structures, and down core subsamples were wet sieved to determine percentage gravel, sand, and mud by dry weight [Harris and $O^{\prime} B r i e n, 1998$ ]. The following geochemical measurements were performed on the 10 cm thick subsamples: (1) bulk major and minor elements ( $\mathrm{Al}, \mathrm{Si}$, $\mathrm{Ti}, \mathrm{Mn}, \mathrm{Fe}, \mathrm{Ni}, \mathrm{Cu}, \mathrm{Zn}, \mathrm{Br}, \mathrm{Mo}, \mathrm{Ba}$, and $\mathrm{U}$ ) were determined in crushed, $60^{\circ} \mathrm{C}$ dried (and, for major elements, deionized water washed) material by X-ray fluorescence spectroscopy, following a modification of the method of Shimmield [1984]; (2) biogenic silica (opal), with assumed composition $\mathrm{SiO}_{2} \cdot 0.4 \mathrm{H}_{2} \mathrm{O}$, was determined in freeze-dried sediment by the method of Mortlock and Froelich [1989]; and (3) total organic carbon (TOC) was determined in crushed, $60^{\circ} \mathrm{C}$ dried, acid-treated, deionized water washed material using an elemental analyzer at the Australian Geological Survey Organization or the University of Tasmania. Analytical uncertainties, as estimated from repeated measurements of in-house standards, are presented in Table 1 (the geochemical data presented here are available electronically at http://www.antcrc.utas.edu.au/antcrc/research/sediment_web/data /geochem.html).

\section{Results}

\subsection{Core Preservation and Chronostratigraphy}

Table 2 presents the radiocarbon ages and measured or assumed $\delta^{13} \mathrm{C}$ values of bulk organic carbon in subsamples from the five cores. The measured $\delta^{13} \mathrm{C}$ values are generally consistent with the range of -20 to $-30 \%$ reported for Southern Ocean pelagic phytoplankton [Gibson et al., 1999; Popp et al., 1999], although slightly lower values $(<-32 \%$ ) in the upper portion of core AA149-GC12 may reflect the presence of ${ }^{13} \mathrm{C}$-depleted relict terrestrial organic matter [Harris et al., 1996]. Down core radiocarbon ages generally increase in a regular fashion (Figure 3) and suggest that the cores preserve continuous records of sediment accumulation over time periods ranging from $-3.8 \mathrm{kyr}$ (AA149GC2) to $15 \mathrm{kyr}$ (AA149-GC12). Our initial analyses of core top samples from cores KROCK-GCl and KROCK-GC2 detected no unsupported ${ }^{210} \mathrm{~Pb}$ [Sedwick et al., 1998], suggesting the loss of sediments corresponding to the past $\sim 100-200$ years (at least) of accumulation during collection of these cores. Subsequent analyses (data not shown) indicate low levels of unsupported ${ }^{210} \mathrm{~Pb}$ in only the upper $2 \mathrm{~cm}$ of cores AA186-GC34 and KROCK$\mathrm{GC} 2$, and no unsupported ${ }^{210} \mathrm{~Pb}$ in core KROCK-GC1, consistent with some loss of core top material during collection, whereas the
Table 1. Estimated Analytical Uncertainties

\begin{tabular}{ll}
\hline Species & Uncertainty $^{\mathbf{a}}$ \\
\hline $\mathrm{Al}$ & 0.5 \\
$\mathrm{Si}$ & 0.2 \\
$\mathrm{Ti}$ & 5 \\
$\mathrm{Mn}$ & 10 \\
$\mathrm{Fe}$ & 2 \\
$\mathrm{Ni}$ & 10 \\
$\mathrm{Cu}$ & 10 \\
$\mathrm{Zn}$ & 1 \\
$\mathrm{Br}$ & 10 \\
$\mathrm{Mo}$ & 5 \\
$\mathrm{Ba}$ & 1 \\
$\mathrm{U}$ & 20 \\
Opal & 5 \\
$\mathrm{TOC}$ & $0.2^{\mathrm{b}}$ \\
\hline
\end{tabular}

aRelative standard deviation on mean.

low to moderate levels of unsupported ${ }^{210} \mathrm{~Pb}$ measured in the upper $5 \mathrm{~cm}$ of cores AA149-GC2 and AA149-GC12 suggest that there were no significant core top losses.

In our study region the radiocarbon age of organic matter at the sediment-water interface is expected to be greater than zero as a result of (1) the nonzero radiocarbon age of the dissolved inorganic carbon that is converted into organic matter in the euphotic zone (assumed to be the principal source of organic carbon in our sediment cores), termed the reservoir effect, which is $\sim 1300$ years in surface waters of the Southern Ocean [Gordon and Harkness, 1992; Berkman and Forman, 1996]; (2) bioturbation in the upper sediment column, which vertically mixes material over depths of the order of $10 \mathrm{~cm}$ [Berner, 1980; Libes, 1992]; and (3) dilution of fresh sediments by older, resuspended particulate carbon [Harris et al., 1996]. In an effort to correct our radiocarbonbased chronologies for the combined effects of these processes, we have subtracted 1730 radiocarbon years from our raw radiocarbon ages. This value of 1730 radiocarbon years is the raw radiocarbon age of a well-stratified, water-saturated, surface sediment grab sample (AA186-GB9) that was recovered near the location of AA149-GC2 in the inner Nielsen Basin (E. Domack, personal communication, 1997). The radiocarbon age of this surface sediment sample is assumed to be representative of surface sediments within the shelf basins of our study area.

We recognize that there are a number of significant uncertainties included in our radiocarbon age correction. One is the possible geographic variation in radiocarbon age of surface sediments in these shelf basins, which might be expected, for example, because of differences in the proportion of resuspended material accumulating at different locations. Another uncertainty is introduced by the likely variation in the reservoir age of Antarctic waters between the Last Glacial Maximum and the early Holocene, which may be of the order of thousands of years, based on our knowledge of changes in the radiocarbon age of oceanic deep waters over this period [Samson, 1999; Sikes et al., 2000] and given that upwelled deep waters dominate the radiocarbon inventory of Antarctic surface waters [Berkman and Forman, 1996]. Yet an additional complication to the radiocarbon age correction is introduced by the presence of bomb- 
Table 2. Radiocarbon Ages

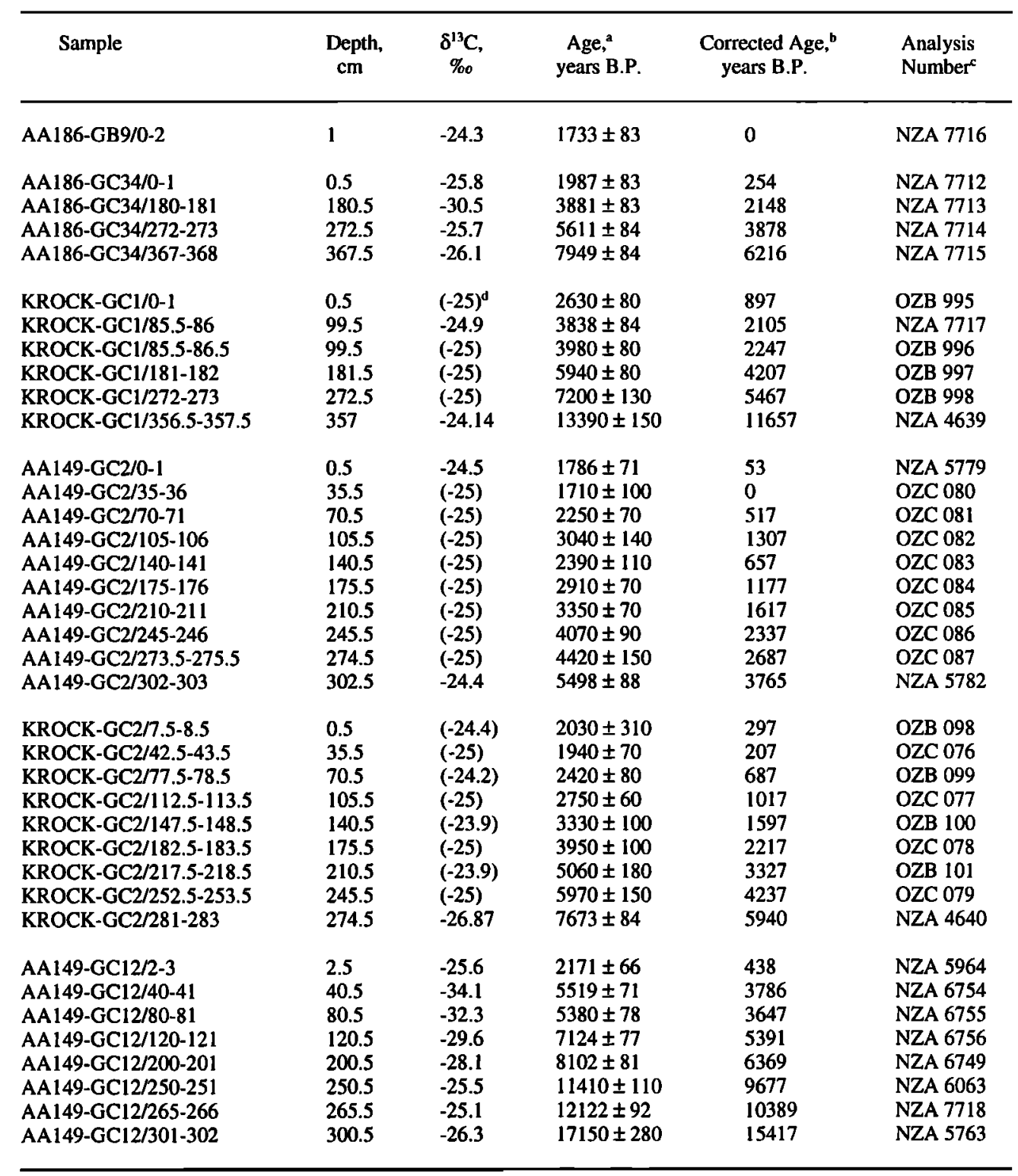

${ }^{a}$ Radiocarbon years B.P. as defined by Stuiver and Polach [1977].

${ }^{\circ}$ Corrected age assumes surface sediment age of 1733 radiocarbon years B.P.

'Sample numbers beginning with OZ analyzed by the Australian Nuclear Science and Technology Organization, and sample numbers beginning with NZ analyzed by the New Zealand Institute of Geological and Nuclear Sciences.

${ }^{d} V$ alues in parentheses are assumed for the calculation of radiocarbon ages.

derived radiocarbon in sediments deposited during the past $\mathbf{5 0}$ years, which will have the effect of decreasing the radiocarbon age of recent sediments by as much as $\mathbf{5 0 0}$ years [Berkman and Forman, 1996]. However, in the absence of specific information regarding the effect of these various processes on the radiocarbon age of surface sediments in basins on the Mac. Robertson Shelf, we have corrected all of our raw radiocarbon ages by subtracting 1730 radiocarbon years. The thus corrected ages of our sediment core samples, which we compare against the conventional radiocarbon timescale, are presented in Table 2.

Sediment accumulation rates have been calculated between dated samples in the cores as shown in Figure 3 . These calculated sedimentation rates range from 7 to $500 \mathrm{~cm} \mathrm{kyr}^{-1}$

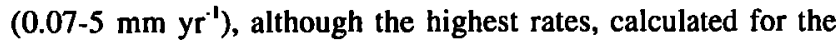
uppermost sections of the cores, have large uncertainties resulting from the analytical uncertainties in the radiocarbon ages. Typical accumulation rates appear to be of the order of $50 \mathrm{~cm} \mathrm{kyr}^{-1}$. Several dated samples were excluded from the accumulation rate calculations in cases where either (1) the sample age is older than the age of the sample immediately below (cores AA149-GC2 and AA149-GC12), suggesting the possible input of older material due to slumping, or (2) the sample age is within analytical uncertainty of the age of the core top sample immediately above (cores AA149-GC2 and KROCK-GC2). The corrected radio- 


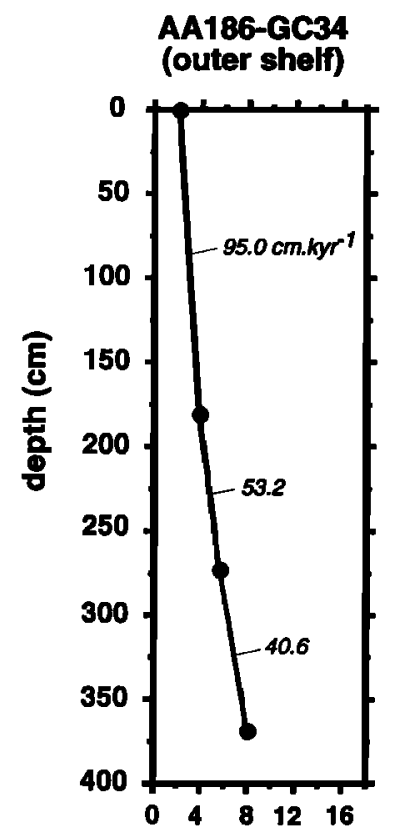

KROCK-GC1 (outer shelf)

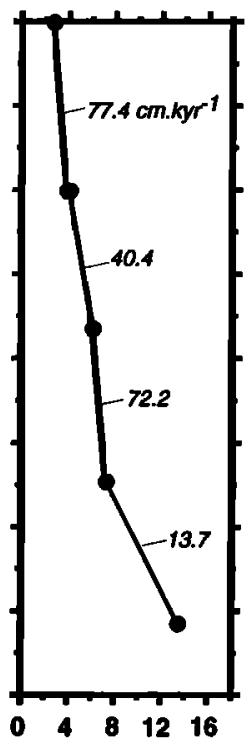

AA149-GC2 (inner shelf)

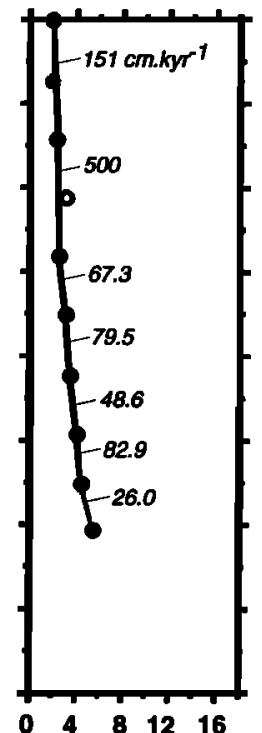

KROCK-GC2 (inner shelf)

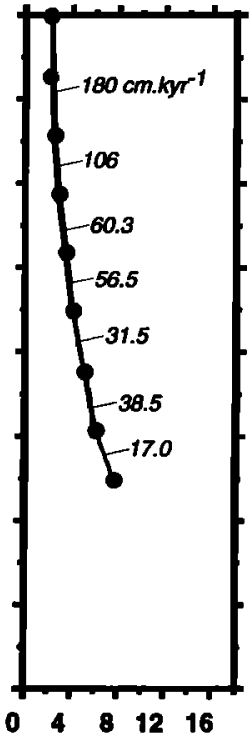

AA149-GC12 (mid-outer shelf)

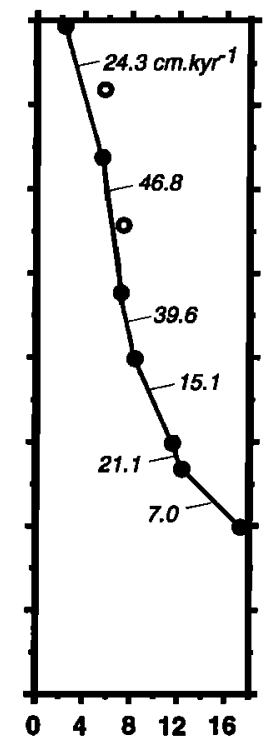

uncorrected radlocarbon age (kyr B.P.)

Figure 3. Uncorrected radiocarbon ages versus depth and calculated sediment accumulation rates between dated samples. Samples were excluded from accumulation rate calculations where (1) a sample is older than that immediately below it (open circles) or (2) a sample age is within analytical uncertainty of the core top sample age (stippled circles).

carbon ages of the core top samples range from $\sim 50$ to 900 radiocarbon years, which may reflect the previously mentioned uncertainties in our age correction, as well as some loss of core top material, although the latter is only likely to be significant (i.e., greater than $-100-200$ years) for cores AA186-GC34, KROCK-GC1, and KROCK-GC2, on the basis of our excess ${ }^{210} \mathrm{~Pb}$ analyses. The corrected core top age of KROCK-GC1, if due solely to core top loss, suggests that $-70 \mathrm{~cm}$ of the uppermost sediment column is missing, using our estimated accumulation rates. However, as noted above, these accumulation rate estimates and thus estimates of core top losses are very poorly constrained.

Core chronologies were established by linear interpolation of the age versus depth data as shown in Figure 3, using the corrected radiocarbon ages presented in Table 2 . With the exception of core AA149-GC12 (see below), the down core physical data (Figure 2) and X-ray images provide no clear evidence of graded beds or erosional surfaces within the SMO units, and coarse material typical of shallower areas on the shelf, including calcareous biota which occur on nearby Fram Bank [Rathburn et al., 1997], is rare. This and the absence of significant age reversals or hiatuses in the down core radiocarbon ages argues against significant episodic down slope transport of sediments into these basins, or significant erosional events, although the sustained transport of fine sediments from the shallow shelf areas into these basins is clearly an important process [Harris and O'Brien, 1996, 1998]. Thus, in our interpretation of the down core geochemical data we assume that each core contains a continuous record of sediment accumulation that has not been significantly disturbed by slumps, turbidity flows, or erosional events. In the case of core AA149-GC12, however, X- ray images indicate ripple cross bedding concentrated between 50 and $150 \mathrm{~cm}$ depth, which along with radiocarbon age reversals (Figure 3 ) and relatively depleted $\delta^{13} \mathrm{C}$ values $(\leq 30 \%$ ) between 40 and $120 \mathrm{~cm}$ depth (Table 2), suggest that the sediment record in this core may reflect episodes of down slope sediment transport by relatively strong density currents [Harris, 2000].

\subsection{Physical and Geochemical Data}

The SMO units are made up of $70-95 \%$ mud and $~-5-30 \%$ sand (Figure 2) and contain 16-46\% opal (mean is $37 \%$ ) and $0.66-2.3 \%$ TOC (mean is $1.3 \%$ ) by weight. Down core magnetic susceptibility values are uniformly low $\left(<5 \times 10^{-6} \mathrm{cgs}\right)$ and featureless within the SMO facies (Figure 2), indicating a paucity of ferromagnetic minerals and lithogenic material in general. Microscopic examination of core material indicates that the majority of organic matter is associated with the remains of diatoms that are typical of Antarctic coastal and shelf waters, with lithogenic particles (fine sand to coarse silt) accounting for the remainder of the SMO facies material. A detailed microfossil study of cores KROCK-GC1 and KROCK-GC2 [Taylor, 1999; F. Taylor and A. McMinn, Evidence from diatoms for Holocene climate fluctuation along the East Antarctic margin, submitted to The Holocene, 2000] indicates that the diatoms Fragilariopsis curta and Fragilariopsis cylindrus dominate the dark olive green SMO, except near the base of both cores where Chaetoceros spp. resting spores are dominant, whereas the lighter-colored bands in core KROCK-GCl are characterized by an increased abundance of the diatom Corethron criophilum. Preliminary microscopic examination of material from core AA186-GC34 suggests that the light and dark banding in this core reflects diatom species 
assemblages similar to those in core KROCK-GCl (L. Armand, personal communication, 1999). The occurrence of the larger visible "Corethron layers" in these cores is indicated in Figure 2.

In examining the paleoenvironmental record preserved in these cores, specifically the record of accumulation of biogenic versus lithogenic material, the physical measurements are of only limited use at the level of resolution used in this study because of the relatively homogeneous grain size distribution and the relatively low and constant values of magnetic susceptibility. We have therefore focused on chemical proxies for the accumulation of lithogenic and biogenic material in an effort to infer the sedimentation histories for these core sites. The chemical data considered here are divided into the following groups on the basis of their utility as paleoenvironmental proxies.

1. Ti, Al, and Fe, the major fractions of which are generally associated with lithogenic material in pelagic and hemipelagic sediments [Calvert and Pedersen, 1993; Kumar et al, 1995]. Bulk sediment concentrations of these elements thus provide a relative measure of the accumulation of lithogenic material.

2. TOC and $\mathrm{Br}$, which provide relative measures of the accumulation of organic matter in marine sediments. TOC provides a direct measure of the deposited organic matter remaining after diagenetic remineralization, whereas $\mathrm{Br}$ is thought to be uniquely controlled by the organic fraction in marine sediments [Price et al., 1970; Calvert and Pedersen, 1993].

3. Opal and total $\mathrm{Si} / \mathrm{Al}$, both of which provide relative measures of the accumulation of biogenic siliceous matter where postdepositional preservation is high or relatively constant [Charles et al., 1991; Mortlock et al., 199]; McManus et al., 1995]. Opal determined by the method of Mortlock and Froelich [1989] provides a direct measure of this biogenic silica, whereas total Si (determined by X-ray fluorescence), when normalized to $\mathrm{Al}$, provides an indirect estimate of this same quantity, assuming that the majority of $\mathrm{Al}$ is lithogenic.

4. Mo, U, and Mn, which change valence and are thus adsorbed or precipitated in response to changes in sedimentary redox conditions. Sedimentary enrichments in Mo/Al, U/Al, and $\mathrm{Mn} / \mathrm{Al}$, relative to crustal abundances (assuming all $\mathrm{Al}$ is lithogenic), are indicative of anoxic (sulfidic), suboxic, and oxic conditions, respectively [Calvert and Pedersen, 1993, 1996; Crusius et al., 1996]. Thus these elements serve as sensitive proxies of sedimentary redox conditions, with down core changes in Alnormalized concentrations indicating past variations in redox conditions, as may result from variations in the accumulation of organic matter.

5. $\mathrm{Ni}, \mathrm{Cu}$, and $\mathrm{Zn}$, which form insoluble metal sulfides and may thus precipitate in reducing sediments where dissolved sulfide is present [Calvert and Pedersen, 1993]. Sedimentary enrichments in $\mathrm{Ni} / \mathrm{Al}, \mathrm{Cu} / \mathrm{Al}$, and $\mathrm{Zn} / \mathrm{Al}$ relative to crustal abundance (assuming all $\mathrm{Al}$ is lithogenic) are indicative of anoxic (sulfidic) conditions, as may result from increased accumulation of organic matter.

6. Biogenic (or excess) $\mathrm{Ba}$, calculated as the difference between total and lithogenic $\mathrm{Ba}$, where lithogenic $\mathrm{Ba}$ is estimated from $\mathrm{Al}$ using the average crustal weight ratio of $\mathrm{Ba} / \mathrm{Al}(0.0075)$. Biogenic $\mathrm{Ba}$ is thought to be delivered to the sediments as barite contained in organic matter from the surface ocean and is well preserved in oxic sediments, where it serves as a proxy for export production in overlying waters [Dymond et al., 1992].

These chemical data are presented in Figure 4, in which bulk sediment concentrations (dry weight basis) are plotted against the age corresponding to the average depth of each subsample in the core. These ages were linearly interpolated using the chronological scheme described in section 3.1. The periods of deposition integrated by these $10 \mathrm{~cm}$ thick subsamples range from $\sim 20$ years (base of AA149-GC12) to 1400 years (upper portion of AA149. $\mathrm{GC2}$ ), based on the estimated sediment accumulation rates shown in Figure 3, with a typical temporal resolution of $\sim 200$ years for a sediment accumulation rate of $50 \mathrm{~cm} \mathrm{kyr}^{-1}$.

\section{Discussion}

\subsection{Down Core Compositional Records}

The SMO units of the five cores are generally similar in terms of bulk composition, with cores KROCK-GC1 and AA149-GC12 displaying the greatest compositional ranges, as is evident in the down core opal data (Figure 4). Manganese concentrations are uniformly low in all of the cores, with $\mathrm{Mn} / \mathrm{Al}$ values (mean is $0.16 \pm 0.27$ ) statistically indistinguishable from the average shale ratio of 0.08 [Wedepohl, 1971], whereas the ratios Mo/Al (mean is $1.3 \pm 0.6 \times 10^{-4}$ ) and $\mathrm{U} / \mathrm{Al}$ (mean is $0.9 \pm 0.3 \times 10^{-4}$ ) are significantly enriched relative to the average shale ratios of $\sim 0.3 \times 10^{-4}$ and $\sim 0.4 \times 10^{-4}$, respectively [Wedepohl, 1971]. These geochemical trends together with shipboard observations of hydrogen sulfide odor upon recovery of these cores and grab sample AA186-GB9 indicate that the entire sediment column and possibly the sediment-water interface were anoxic (sulfidic) at each of these sites. This would act to limit bioturbation by benthic organisms, thus favoring the preservation of highresolution records of sediment accumulation. However, the presence of hydrogen sulfide in the sediment column also precludes the use of biogenic $\mathrm{Ba}$ as a productivity proxy, since dissolution of sedimentary barite accompanies sulfate reduction [Dymond et al., 1992]. Indeed, the down core records show that biogenic $\mathrm{Ba}$ does not vary in concert with the other proxies of organic matter accumulation, with some calculated values being close to or less than zero (Figure 4). A similar situation is likely to apply in sediments from other basins on the Antarctic margin, such as the Palmer Deep, where sedimentary $\mathrm{Al}$ and Ba concentrations [Rodriguez and Domack, 1994] sometimes yield negative values for biogenic $\mathrm{Ba}$.

The geochemical records of the two outer shelf cores AA186GC34 and KROCK-GCl (Figures 4a and 4b) show several prominent minima in the lithogenic elements $\mathrm{Ti}, \mathrm{Al}$, and $\mathrm{Fe}$, which are generally coincident with small maxima in the biogenic components $\mathrm{TOC}, \mathrm{Br}$, opal, and $\mathrm{Si} / \mathrm{Al}$ and also coincident with maxima in Mo/Al and, in some cases, U/Al and $\mathrm{Zn} / \mathrm{Al}$. These features are indicated by the stippled bands in Figure 4, each of which is 500 years in thickness. We suggest 500 years as a conservative estimate of the uncertainty in the timing of these chemical features, given that the subsamples used for geochemical analysis typically integrate several centuries of accumulation and the chronological uncertainties of $60-280$ years in our radiocarbon dates. These minima in lithogenic components are also generally coincident with down core minima in sand content (Figure 2) and maxima in water content (data not shown). In core AA186-GC34, all of these features coincide with light-colored Corethron layers, whereas for KROCK-GCl, three of five lithogenic minima coincide with Corethron layers, while a fourth occurs in the Chaetoceros layer near the bottom of the core. These observations immediately suggest that the down core 


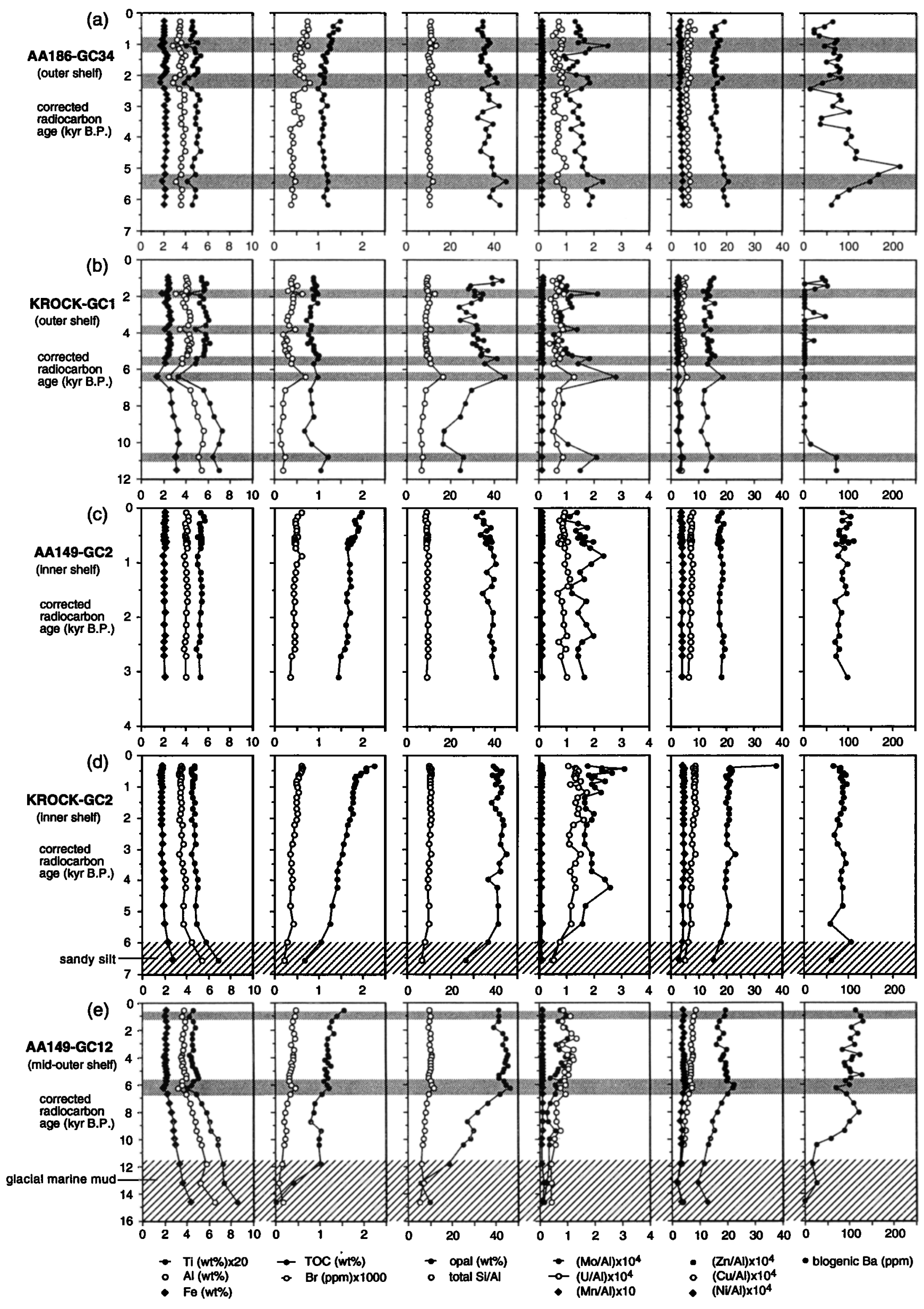

Figure 4. 


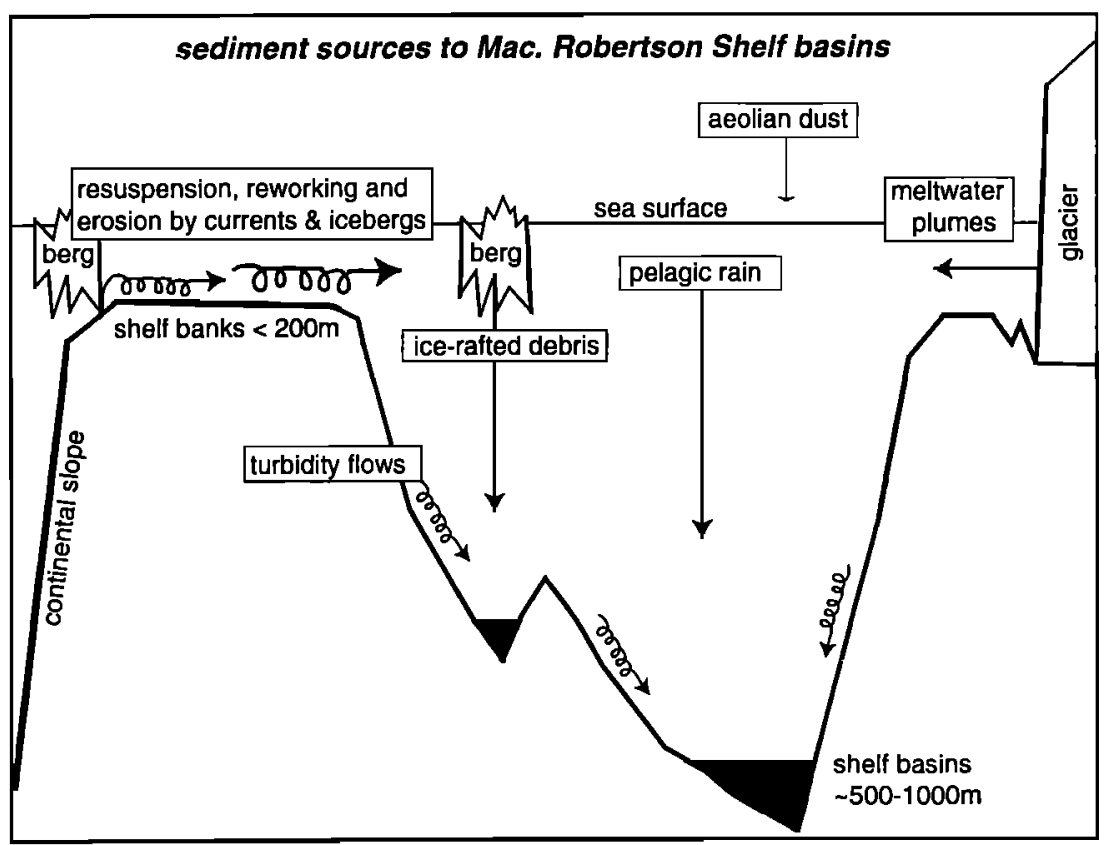

Figure 5. Major sediment sources to the Mac. Robertson Shelf basins. Modified from Figure 10 of Harris and $O^{\prime} B r i e n$ [1996], (O) Springer-Verlag 1996.

minima in lithogenic elements may record enhanced deposition of pelagic biogenic material on the surrounding shelf, perhaps due to blooms of Corethron or Chaetoceros in these waters.

The inner shelf cores AA149-GC2 and KROCK-GC2 contain generally finer-grained sediments (Figure 2) and higher concentrations of TOC, opal, and Mo (Figures $4 \mathrm{c}$ and 4d) than the outer shelf cores, suggesting either enhanced deposition of biogenic material relative to lithogenic material in the inner shelf basins or enhanced preservation of organic matter in these locations, which would create more reducing conditions in the sediment column. In contrast to the outer shelf cores, the down core records of the two cores from the inner Nielsen Basin contain no significant minima in lithogenic components. Rather, the relative proportions of lithogenic and biogenic material which has accumulated at these sites has been remarkably uniform during the middle to late Holocene, before which this area was probably covered by a floating ice shelf [Harris and O'Brien, 1998]. In both cores, there are significant decreases in TOC content with increasing sediment age, which may reflect an increase in the accumulation of organic carbon during the late Holocene or, more likely, since there are no corresponding trends in biogenic silica, the progressive diagenetic remineralization of TOC within the sediment column [Berner, 1980; Domack and McClennen, 1996].

Not surprisingly, the chemical record of core AA149-GC12 (Figure 4e), from midshelf of the Nielsen Basin, is generally intermediate between the inner and outer shelf core records. Minima in lithogenic components are discernible at $\sim 6 \mathrm{kyr}$ B.P. and possibly $\sim 1$ kyr B.P., as are small maxima in the biogenic components, and there is a steady decrease in the proportion of lithogenic components from $\sim 11$ to $6 \mathrm{kyr}$ B.P. In contrast to the other cores, $\mathrm{Mo} / \mathrm{Al}$ values are less than U/Al, suggesting lower concentrations of hydrogen sulfide, thus less reducing conditions, within the sediment column at this site. This observation suggests a slower accumulation of organic matter at this location during the Holocene compared with the other core sites and is consistent with the sediment accumulation rates calculated for AA149-GC12, which are generally less than those calculated for contemporaneous sections of the other cores in this study (Figure 3). This likely reflects a lesser degree of sediment focusing (see below) at the site of core AA149-GC12, which is not within the central axis of the Nielsen Basin (Figure 1), as well as episodic ventilation by sinking, oxygenated surface waters in this area of the shelf [Harris, 2000].

\subsection{Paleoenvironmental Interpretation}

In order to interpret our proxy records for the accumulation of biogenic and lithogenic material we must first consider the sources of the SMO facies sediments in the Mac. Robertson Shelf basins. The major sources of sediments in these basins are shown schematically in Figure 5, as proposed by Harris and $O^{\prime} B$ rien [1996]. Under seasonally open marine conditions the basins will have received sediments from overlying waters in the form of pelagic rain (biogenic material), ice-rafted debris (lithogenic material), glacial meltwater plumes (lithogenic material), and aeolian dust (lithogenic material). In addition, a mixture of biogenic and lithogenic material will have been transported laterally into the basins from the shallower areas of the shelf as a result of

Figure 4. Down core geochemical data for the five cores in this study. Stippled bands indicate inferred production episodes; hatching indicates sandy silt or glacial marine facies. Estimated analytical uncertainties $( \pm 2 \sigma)$ shown by width of symbols/bars along bottom axis. 
resuspension and erosion by currents, icebergs, and turbidity flows. Harris and O'Brien [1996] have noted that net erosional conditions exist over $\sim 90 \%$ of the Mac. Robertson Shelf, where coarse-grained sediments dominate the shallow banks and slopes, whereas net depositional conditions exist on the remaining $10 \%$ of the shelf area, as represented by the accumulation of finegrained SMO deposits in the shelf basins. A similar sedimentation pattern has been described for other parts of the Antarctic margin, including the Ross Sea, the Northern Victoria Land Shelf, and the Wilkes Land Shelf [Anderson et al., 1984; Dunbar et al., 1985; Anderson, 1999].

The general absence of coarse lithogenic material, graded beds, and erosional surfaces in our cores argues against significant lateral transport of sediments into the shelf basins by icebergs, slumps, and turbidity flows, except in the case of core AA149-GC12, which shows evidence of episodic down slope sediment transport by density currents (as described in section 3.1 and Harris [2000]). In addition, swell waves and tidal currents are thought to play a minor role in reworking shelf sediments in our study region [Harris and $O^{\prime} B r i e n, 1998$ ]. On the basis of these considerations and the observations of relatively strong bottom currents on the Mac. Robertson Shelf [Harris and O'Brien, 1998] we suggest that the shelf-basin SMO deposits are dominated by fine-grained material which has been winnowed from the shallow banks and slopes, mainly by the action of currents, with a lesser contribution of sediments derived from overlying waters. The major current involved in this process would be the Antarctic Coastal Current, a strong, circumpolar current driven by the East Wind Drift and the density gradient across the Antarctic Slope Front [Smith et al., 1984; Harris and O'Brien, 1998; Bindoff et al., 2000]. Current measurements from the Mac. Robertson Shelf suggest that this current flows consistently toward the west, with maximum speeds of 50-200 $\mathrm{cm} \mathrm{s}^{-1}$ on the outer shelf, with some reduction in strength during the winter and spring [Harris and O'Brien, 1998]. Such current speeds would certainly be sufficient to mobilize mud and fine sand from the shallow banks and slopes, which would be redeposited in the downstream shelf basins and would account for the accumulation of finer sediments in basins on the inner shelf, where current speeds are less.

This west flowing current regime has probably existed on the Mac. Robertson Shelf during most of the Holocene, so that there has been a roughly continuous transport of fine biogenic and lithogenic material (i.e., SMO) into these basins from the shallow shelf areas to the east. Thus the undisturbed sediments which have accumulated in these basins during the Holocene will most likely provide us with a record of the production and deposition of fine sediments, both biogenic and lithogenic, over larger areas of the adjacent, upstream banks. This scenario provides a likely explanation for the apparent increases in sediment accumulation rates during the course of the Holocene that are indicated by the data in Figure 3. Harris and O'Brien [1998] have argued that the glacial ice sheet began to retreat from its grounding position on the middle to outer shelf at $\sim 10-12 \mathrm{kyr}$ B.P., and that the calving front of the floating ice sheet had retreated to the inner shelf, near the location of KROCK-GC2, by $\sim 6 \mathrm{kyr}$ B.P. If so, then the seasonally ice-free area of the Mac. Robertson Shelf would have increased significantly between the early and late Holocene, which would be expected to allow the current-driven transport of fine material into the shelf basins from progressively larger "catchment areas" on the shelf. In the remaining discussion, we assume that the SMO sequences contained in our five sediment cores provide a record of the deposition and erosion of fine sediments on the shallow shelf areas immediately to the east, with the exception of the section of core AA149-GC12 that is thought to be disturbed by down slope sediment transport.

What processes might explain the down core variations in the proportions of lithogenic and biogenic components preserved in our middle and outer shelf cores? There are two likely alternatives. The first is that these variations may reflect changes in the current-driven transport of biogenic and lithogenic material into the basins from the shallow areas of the shelf, such that the lithogenic minima in our cores may record periods of lower current speeds, which favor the transport of only the finer biogenic material, such as diatom frustules, from the shelf banks into the basins. This would lead us to expect significantly lower sediment accumulation rates in association with these lithogenic minima; however, we see no evidence for such variations in accumulation rates. Moreover, it is difficult to explain the corresponding down core variations in diatom species abundances, specifically the occurrence of Corethron-rich layers, as the result of changes in current-driven resuspension. A more likely alternative is that the down core variations in the proportions of lithogenic and biogenic material may reflect changes in the production and deposition of biogenic material over the shallow shelf areas, such that the lithogenic minima may record periods of enhanced diatom production in shelf waters upstream of the core sites.

A similar interpretation of down core minima in lithogenic components and corresponding variations in diatom species assemblages has been adopted in other studies of sediment cores from Antarctic shelf basins [e.g., Domack et al., 1993; Leventer et al., 1996; Leventer and Dunbar, 1996; Domack and Mayewski, 1999; Domack et al., 2001]. Thus we interpret the down core minima in lithogenic components in our middle and outer shelf cores as indicative of "production episodes," representing sustained periods of high export production by diatoms in the shelf waters immediately to the east of these shelf basins. The increased accumulation of organic matter in the shelf basins associated with such production episodes would be expected to create more reducing, sulfide-rich conditions within the sediment column, as suggested by the Mo/Al, U/Al and $\mathrm{Zn} / \mathrm{Al}$ maxima, which approximately coincide with minima in lithogenic components. That most of these chemical features roughly coincide with Corethron layers in cores AA186-GC34 and KROCK-GC1 suggests that these production episodes entailed massive blooms of this diatom species in the outer shelf region, given that Corethron criophilum is a relatively lightly silicified diatom species that is thought to be poorly preserved in seafloor sediments [Jordan et al., 1991; Leventer et al., 1993, 1996].

\subsection{Timing and Forcing of Production Episodes}

We assume that the transport of fine sediments from the shallow shelf areas into the basins is relatively rapid, so that within the resolution of our radiocarbon chronologies the compositional changes preserved in the middle and outer shelf cores are coeval with depositional changes over the upstream areas of the Mac. Robertson Shelf. However, the actual duration of the production episodes inferred from these core records is 


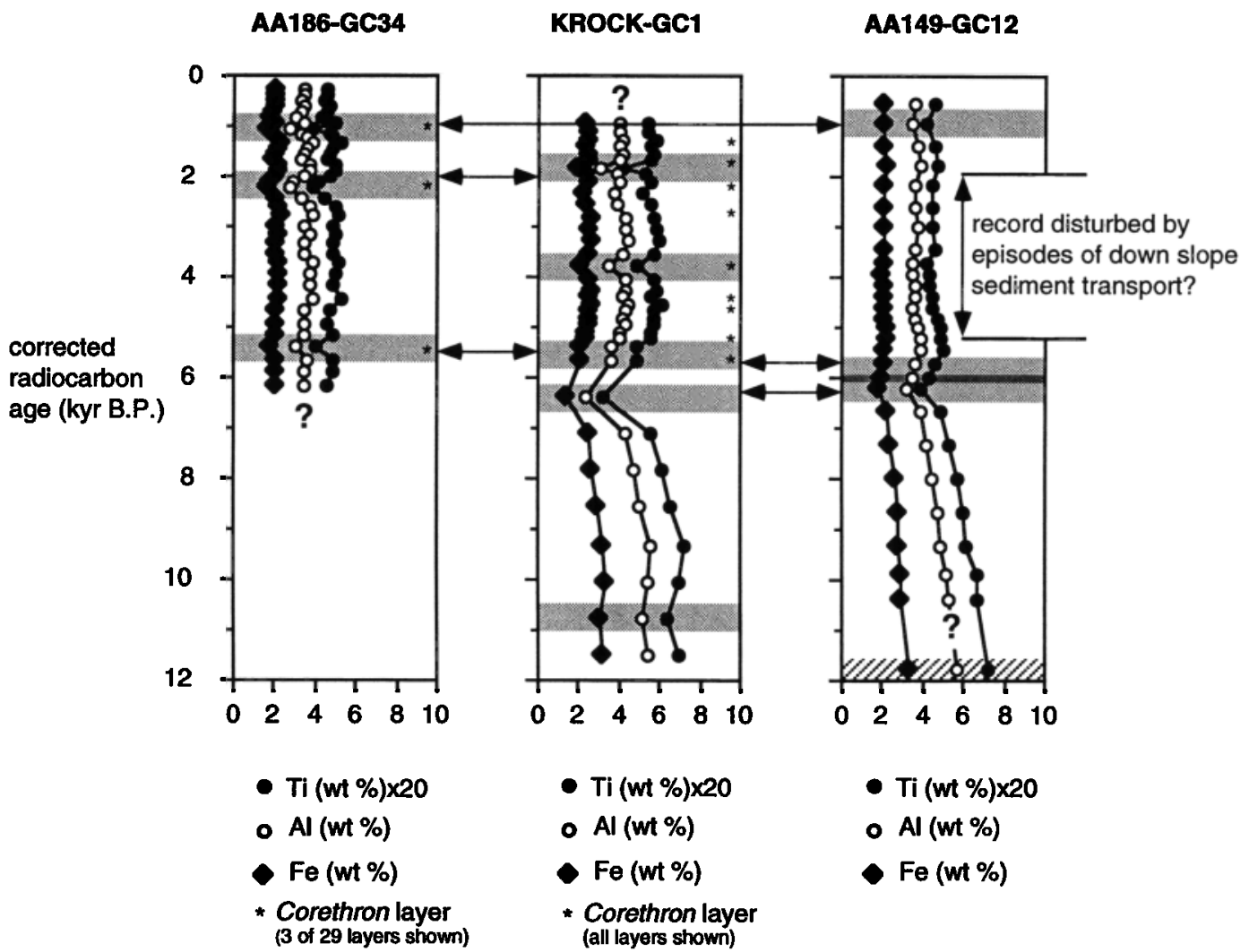

Figure 6. Comparison of timing of production episodes (stippled bands) recorded in the outer and middle shelf cores.

highly uncertain. On the basis of our rather coarse-resolution radiocarbon chronologies, these production episodes lasted of the order of 100-1000 years, although such sediment layers might have accumulated over much shorter periods, given their relatively high water content and our limited stratigraphic resolution. We also note that many of the light-colored layers in the outer shelf cores are only $\sim 1-3 \mathrm{~cm}$ in thickness, in which case it would be unlikely that such features would be resolved by our geochemical data, which apply to $10 \mathrm{~cm}$ thick down core subsamples. Thus the production episodes which we have inferred from our down core composition data probably represent only the more sustained and/or frequent episodes of export production in adjacent shelf waters.

In Figure 6, we compare the approximate timing of these production episodes in cores AA186-GC34, KROCK-GC1, and AA149-GC12, as indicated by concentration minima in $\mathrm{Ti}, \mathrm{Al}$, and $\mathrm{Fe}$ and the occurrence of Corethron layers in the Iceberg Alley cores. Relative to our corrected radiocarbon chronology, production episodes are indicated at around 1, 2, and $6.2 \mathrm{kyr}$ B.P. in two of the three records, whereas all three core records indicate an episode at $\sim 5.5 \mathrm{kyr}$ B.P. Only core KROCK-GC1 shows evidence of production episodes at $\sim 3.8$ and $10.8 \mathrm{kyr}$ B.P., although these episodes may be obscured or unresolved in core AA149-GC12 and the AA186-GC34 record extends back only as far as $\sim 6.2 \mathrm{kyr}$ B.P. The only other reported Holocene sediment records from this region of the East Antarctic shelf are those inferred from microfossil assemblages in two cores from Fram Bank, $\sim 100 \mathrm{~km}$ to the east of the Nielsen Basin, where there is evidence of enhanced export production during the period $\sim 2.6$ 3.4 kyr B.P. [Rathburn et al, 1997]. This period of higher production does not correspond with the timing of the production episodes in our Mac. Robertson Shelf records; however, we note that Rathburn et al. [1997] corrected their radiocarbon ages by subtracting 1300 radiocarbon years, accounting only for the reservoir effect. Applying a larger radiocarbon age correction of the order of 1700 years (see section 3.1) to the raw radiocarbon dates of Rathburn et al. [1997] places the Fram Bank highproduction period at $-2.2-3 \mathrm{kyr}$ B.P., which then overlaps with the $\sim 1.6-2.5 \mathrm{kyr}$ B.P. production episodes indicated in our Iceberg Alley cores (Figure 6).

On the basis of comparisons of sediment records from the Antarctic Peninsula shelf with Northern Hemisphere paleoclimate records it has been suggested that periods of elevated productivity inferred from the Antarctic marine records reflect global warm cycles with periods of $\sim 400,200$, and 50-70 years superimposed upon longer-term periods of low-productivity corresponding to global cooling events [Leventer et al., 1996; Domack and Mayewski, 1999; Domack et al., 2001]. To date, the most detailed Holocene sediment records from the Antarctic shelf region are those preserved in cores collected from the Palmer Deep, off the Antarctic Peninsula, during Ocean Drilling Program Leg 178. High-resolution paleoproductivity records have been derived from these cores using down core magnetic susceptibility measurements and radiocarbon dating [Domack et al., 2001]. The production episodes inferred from our Mac. Robertson Shelf cores AA186-GC34, KROCK-GC1, and AA149-GC12 (Figure 6) 
are roughly coeval with high-productivity periods inferred from the Palmer Deep records [Domack et al., 2001] as well as a midHolocene productivity high inferred from Ross Sea sediment records [Jacobson, 1997; Frignani et al., 1998; Cunningham et al., 1999], suggesting that there may have been circum-Antarctic periods of enhanced export production during the Holocene in response to global climatic forcing. However, such comparisons must be made with caution, and the apparent agreement between core records from the Mac. Robertson Shelf, the Palmer Deep, and the Ross Sea may be simply fortuitous, given the uncertainties in our radiocarbon chronology and the limited temporal resolution of our geochemical data.,

What were the immediate forcing mechanisms responsible for these inferred episodes of enhanced production on the Mac. Robertson Shelf, and why are no such production episodes indicated by the inner shelf cores? The factors which control algal export production and community structure in Antarctic waters are not well understood but are likely to include vertical stability of the upper water column [Smith and Nelson, 1990; Sakshaug et al., 1991; Arrigo et al., 1998a, 1999], seeding by sea ice algae [Smith and Nelson, 1986; Leventer and Dunbar, 1996], grazing by zooplankton [Lancelot et al., 1993; DiTullio and Smith, 1996], light limitation due to sea ice cover and self shading [Smith et al., 1996], availability of micronutrient elements such as iron [Martin et al., 1990; Sedwick and DiTullio, 1997; Sedwick et al., 2000], and more rarely, depletion of macronutrients [Tréguer and Jacques, 1992]. In studies of sediment records from the Antarctic Peninsula continental shelf, periods of enhanced organic matter accumulation have been attributed to enhanced biological production during periods of warm and/or less windy climate, as a consequence of decreased sea ice cover and increased water column stratification, the latter resulting from decreased wind mixing, warmer sea surface temperatures, and increased meltwater inputs [e.g., Leventer et al., 1996; Domack and Mayewski, 1999]. In addition, an increased abundance of Corethron criophilum and Chaetoceros resting spores in sediments from the Ross Sea and the Antarctic Peninsula shelf has been ascribed to enhanced water column stratification [Leventer et al., 1993, 1996].

In considering possible causes for the productivity episodes recorded in our cores from the Mac. Robertson Shelf, we note that most of these features may reflect massive Corethron blooms in adjacent shelf waters, with the exception of the production episode recorded at $\sim 10.8 \mathrm{kyr}$ B.P. in core KROCK-GC1, which apparently records production of Chaetoceros resting spores associated with the retreat of a permanent ice cover. In contrast, the sediment cores from the inner Nielsen Basin suggest relatively uniform export production in upstream shelf waters. With the exception of the base of core KROCK-GC2, biogenic material in these SMO sequences is dominated by the diatom Fragilariopsis curta, which is thought to be favored in icemarginal environments [Leventer et al., 1993]. Satellite observations obtained in recent years have revealed the existence a persistent coastal polynya on the inner Mac. Robertson Shelf, the Cape Darnley polynya, which is probably maintained by the presence of icebergs grounded on the shallow banks off Cape Darnley $\left(\sim 70^{\circ} \mathrm{E}\right)$ [Massom et al., 1998]. Satellite advanced very high resolution radiometer images obtained during 1997-1999 (see http://www.antcrc.utas.edu.au/avhrr/mawson/archive/) reveal that the ice-free waters of this polynya extend west from Cape
Darnley as far as the inner Nielsen Basin during the spring and summer, whereas the outer shelf waters are covered by pack ice during the spring and sometimes into the summer. If we assume that a similar pattern of seasonal ice cover has existed since the middle Holocene, by which time the glacial ice shelf had retreated to the inner continental shelf, then the location of the Cape Darnley polynya provides a likely explanation for the differences between the inner and outer shelf core records.

During the middle to late Holocene, the ice-marginal, wellmixed open waters of the Cape Darnley polynya may have favored consistent interannual production by $F$. curta during the spring and summer, which would have resulted in the consistent transport of fine, biogenic-rich sediments into the inner Nielsen Basin by the relatively weak inner shelf bottom currents. In contrast, the often ice-covered waters of the outer Mac. Robertson Shelf may have experienced much more variable algal production during the spring and summer as a result of interannual variations in sea ice cover. Moreover, unlike the windmixed open waters of the polynya, the outer shelf waters would be more likely to maintain a stable upper water column as a result of enhanced sea ice melting during warmer years. In this scenario, algal production and community composition upstream of the outer shelf basins would have been strongly modulated by the extent of sea ice melting during the spring and summer, whereas water column conditions and algal production to the east of the inner Nielsen Basin were "buffered" by the presence of the Cape Darnley polynya. From these considerations we suggest that the production episodes recorded in our outer shelf cores from Iceberg Alley and more weakly in the midshelf core from the Nielsen Basin record years of enhanced sea ice melting during climatic warm periods, when factors such as a meltwaterstratified water column [Leventer et al., 1996] and ice-derived iron inputs [Sedwick et al., 2000] stimulated massive blooms of diatoms, particularly Corethron criophilum, on the outer Mac. Robertson Shelf.

\subsection{Conclusions and Future Work}

Our interpretations of sediment records from the Mac. Robertson Shelf basins are generally consistent with other Holocene sediment records from the Antarctic margin in that they provide evidence of millennial-scale episodes of enhanced diatom production in outer shelf waters, including a midHolocene "warm period" between $\sim 5$ and 7 kyr B.P. Such production episodes may be related to increased sea ice melting during global climatic warm periods, although local forcing mechanisms cannot be discounted at this time, given the dearth of sediment records from our study area. Our results also indicate that small-scale regional phenomena, such as coastal polynyas, may strongly influence the sediment records in Antarctic shelf basins, which highlights the need for careful consideration of regional sediment dynamics in paleoenvironmental studies of the Antarctic margin. Further studies are clearly required in order to establish the extent and timing of Holocene paleoenvironmental changes on the East Antarctic margin and, at a more basic level, to clarify the relationship between the sediments accumulating in shelf basins and the processes occurring in overlying waters. Such information can only be provided by increasing the spatial coverage and temporal resolution of sedimentary records from this region for comparison with emerging high-resolution paleoenvironmental records from other areas. 
Acknowledgements. The authors thank Phil O'Brien for collecting core samples and providing initial encouragement, Bob Connell and Suenor Woon for laboratory assistance, and Fiona Taylor and Leanne Armand for diatom species identification. Lesley Dowling and Roger Summons of the Australian Geological Survey Organization are thanked for providing TOC and $\delta^{13} \mathrm{C}$ data. John Anderson, Eugene Domack, and Amy Leventer are thanked for their thorough reviews, which greatly improved the manuscript. Uranium series measurements were accomplished with travel funding provided by the Australian Department of Industry, Science and Technology. The staff of the Australian Nuclear Science and Technology Organization AMS facility are thanked for radiocarbon analyses, funded by grants from the Australian Institute of Nuclear Science and Engineering. Principal funding for this work was provided by the Antarctic CRC.

\section{References}

Anderson, J. B., Antarctic Marine Geology, Cambridge Univ. Press, New York, 1999.

Anderson, J. B., and B. F. Molnia (Eds.), GlacialMarine Sedimentation, Short Course in Geol, vol. 9, AGU, Washington, D. C., 1989.

Anderson, J. B., C. F. Brake, and N. C. Myers, Sedimentation on the Ross Sea continental shelf, Antarctica, Mar. Geol., 57, 295-333, 1984.

Arrigo, K. R., D. Worthen, A. Schnell, and M. P. Lizotte, Primary production in Southern Ocean waters, J. Geophys. Res., 103, 15,587-15,600. 1998a.

Arrigo, K. R., A. M. Weiss, and W. O. Smith, Jr., Physical forcing of phytoplankton dynamics in the southwestern Ross Sea, J. Geophys. Res., I03, 1007-1021, 1998b.

Arrigo, K, R., D. H. Robinson, D. L. Worthen, R. B. Dunbar, G. R. DiTullio, M. VanWoert, and M. P. Lizotte, Phytoplankton community structure and the drawdown of nutrients and $\mathrm{CO}_{2}$ in the Southern Ocean, Science, 283. 365-367, 1999.

Baines, P. G., and S. Condie, Observations and modelling of Antarctic downslope flows: A review, Ocean, Ice and Atmosphere: Interactions at the Antarctic Continental Margin, Antarct. Res. Ser., vol. 75, edited by S. S. Jacobs and R. F. Weiss, pp. 29-49, AGU, Washington, D. C., 1998.

Barker, P. F., P. J. Barrett, A. Camerlenghi, A. K. Cooper, F. J. Davey, E. W. Domack, C. Escutia, Y. Kristoffersen, and P. E. O'Brien, Ice sheet history from Antarctic continental margin sediments: The ANTOSTRAT approach, Terra Anfarct., 5, 737 760,1998

Berkman, P. A., and S. L. Forman, Pre-bomb radiocarbon and the reservoir correction for calcareous marine species in the Southern Ocean, Geophys. Res. Lett., 23, 363-366, 1996.

Berner, R., Early Diagenesis, Princeton Univ. Press, Princeton, N. J., 1980.

Bindoff, N. L., M. A. Rosenberg, and M. J. Warner, On the circulation of the waters over the Antarctic continental rise and slope between 80 and $150^{\circ} \mathrm{E}$, Deep Sea Res., Part II, 47, 2299-2326, 2000.

Calvert, S. E, and T. F. Pedersen, Geochemistry of recent oxic and anoxic marine sediments: Implications for the geological record, Mar. Geol., 113. $67.88,1993$.

Calvert, S. E., and T. F. Pedersen, Sedimentary geochemistry of manganese: Implications for the environment of formation of manganiferous black shales, Econ. Geol., 91, 36-47, 1996.

Charles, C. D., P. N. Froelich, M. A. Zibello, R. A. Mortlock, and J. J. Morley, Biogenic opal in Southern Ocean sediments over the last 450,000 years: Implications for surface water chemistry and circulation, Paleoceanography, 6, 697-728, 1991.

Comiso, J C., C. R. McClain, C. W. Sullivan, J. P. Ryan, and C. L. Leonard, Coastal zone color scanner pigment concentrations in the Southern Ocean, J. Geophys. Res., 98, 2419-2451, 1993.

Crusius, J., S. Calvert, T. Pedersen, and D. Sage, Rhenium and molybdenum enrichments in sedıments as indicators of oxic, suboxic and sulfidic conditions of deposition, Eaith Planet. Sci. Lett., 145, 65-78, 1996.

Cunningham, W. L., A. Leventer, J. T. Andrews, A. E. Jennings, and $K$. J. Licht, Late PleistoceneHolocene marine conditions in the Ross Sea,
Antarctica: Evidence from the marine record, Holocene, 9, 129-139, 1999.

Deacon, G., The Antarctic Circumpolar Ocean, Cambridge Univ. Press, New York, 1984.

DiTullio, G. R., and W. O. Smith Jr., Spatial patterns in phytoplankton biomass and pigment distributions in the Ross Sea, J. Geophys. Res., I0I. $18,467-18,477,1996$.

Domack, E. W., Sedimentology of glacial and glacialmarine deposits on the George V-Adelie continental shelf, East Antarctica, Boreas. 11, 79. 97, 1982.

Domack, E. W and C. McClennen, Accumulation of glacial marine sediments in fjords of the Antarctic Peninsula and their use as late Holocene paleoenvironmental indicators, Foundations for Ecosystem Research West of the Antarcfic Peninsula, Antarct. Res. Ser.. vol. 70, edited by R. Ross, E. Hofmann, and L. Quetin, pp. 135-154, AGU, Washington, D. C., 1996.

Domack, E. W., and P. A. Mayewski, Bi-polar ocean linkages: Evidence from late-Holocene Antarctic marine and Greenland ice-core records, Holocene. 9. 247-251, 1999.

Domack, E. W., A. J. T. Jull, J. B. Anderson, T. W. Linick, and C. R. Williams, Application of tandem accelerator mass spectrometry dating to Pleistocene-Holocene sediments of the East Antarctic continental shelf, Quat. Res., 31, 277 $287,1989$.

Domack, E. W., A. J. T. Jull, and S. Nakao, Advance of East Antarctic outlet glaciers during the Hypsithermal: Implications for the volume state of the Antarctic ice sheet under global warming, Geology, 19, 1059-1062, 1991.

Domack, E. W., T. A. Mashiotta, S. E. Ishman, and L. A. Burkley, 300-year cyclicity in organic matter preservation in Antarctic fjord sediments, The Antarctic Paleoenvironment: A Perspective on Global Change, Antarct. Res. Ser., vol. 60, edited by J. Kennett and D. Warnke, pp. 262-272, AGU, Washington, D. C., 1993.

Domack, E. W., E. A Jacobson, S. Shipp, and J. B. Anderson, Late Pleistocene-Holocene retreat of the West Antarctic ice-sheet system in the Ross Sea, part 2, Sedimentologic and stratigraphic signature, Geol. Soc. Am. Bull., I11, 1517-1536, 1999.

Domack, E. W., A. Leventer, R. Dunbar, F. Taylor, S. Brachfeld, C. Sjunneskog, and ODP Leg 178 Scientific Party, Chronology of the Palmer Deep site, Antarctic Peninsula: A Holocene paleoenvironmental reference for the CircumAntarctic, Holocene, $11,1-9,2001$.

Dunbar, R. B., J. B. Anderson, and E. W. Domack, Oceanographic influences on sedimentation along the Antarctic continental shelf, Oceanology of the Antarctic Continental Shelf, Antarct. Res. Ser., vol. 43, edited by S. S. Jacobs, pp. 291-312, AGU. Washington, D. C., 1985.

Dymond, J., E. Suess, and M. Lyle, Barium in deepsea sediment: A geochemical proxy for paleoproductivity, Paleoceanography, 7, 163-181, 1992.

Frignani, M., F. Giglio, L. Langone, M. Ravaioli, and M. Mangini, Late Pleistocene-Holocene fluxes of organic carbon and biogenic silica in the northwestern Ross Sea, Antarctica, Ann. Glaciol., 27, 697-703, 1998.

Gordon, J. E., and D. D. Harkness, Magnitude and geographic variation of the radiocarbon content in Antarctic marine life: Implications for reservoir corrections in radiocarbon dating, Quat. Sci. Rev. II, 697-708, 1992.

Gibson, J. A. E., T. W. Trull, P. D. Nicholls, R. E. Summons, and A. McMinn, Sedimentation of ${ }^{13} \mathrm{C}$ rich organic matter from Antarctic sea-ice algae. A potential indicator of past sea-ice extent, Geology, 27, 331-334, 1999.

Harris, P. T., Ripple cross-bedded sediments on the East Antarctic shelf: Evidence for episodic bottom water production in the Holocene?, Mar. Geol., 170, 317-330, 2000.

Harris, P. T., and P. E. O'Brien, Geomorphology and sedimentology of the continental shelf adjacent to Mac. Robertson Land, East Antarctica: A scalped shelf, Geo. Mar. Leff., 16, 287-296, 1996.

Harris, P. T., and P. E. O'Brien, Bottom currents, sedimentation and ice-sheet retreat facies successions on the Mac Robertson shelf, East Antarctica, Mar. Geol., I5I, 47-72, 1998.

Harris, P. T. P. E. O'Brien, P. Sedwick, and E. M Truswell, Late Quaternary history of sedimentation on the Mac, Robertson Shelf, East Antarctica: Problems with ${ }^{14} \mathrm{C}$-dating of marine sediment cores, Pap. Proc. R. Soc. Tasmania, 130, 47-53, 1996.

Jacobson, E. A., Ice shelf sedimentation and the Holocene climatic optimum in the Ross Sea, Antarctica, B.A. thesis, Hamilton Coll., Cinton, N. Y., 1997.

Jordan, R. W, J. Priddle, C. J. Pudsey, P. F. Barker, and $M$. J. Whitehouse, Unusual diatom layers in upper Pleistocene sediments from the northern Weddell Sea, Deep Sea Res., 38, 829-843, 1991.

Kumar, N., R. F. Anderson, R. A. Mortlock, P. N. Froelich, P. Kubik, B. Dittrich-Hannen, and $M$. Suter, Increased biological productivity and export production in the glacial Southern Ocean, Nature $378,675-680,1995$.

Lancelot, C., S. Mathot, C. Veth, and H. de Baar, Factors controlling phytoplankton ice-edge blooms in the marginal ice-zone of the northwestern Weddell Sea during sea ice retreat 1988: Field observations and mathematical modelling. Polar Biol., 13, 377-387, 1993.

Leventer, A., and R. B. Dunbar, Recent diatom record of McMurdo Sound, Antarctica: Implications for history of sea ice extent, Paleoceanography, 3 , 259-274, 1988.

Leventer, A., and R. B. Dunbar, Factors influencing the distribution of diatoms and other algae in the Ross Sea, J. Geophys. Res., 101, 18,489-18,500, 1996.

Leventer, A., R. B. Dunbar, and D. J. DeMaster, Diatom evidence for late Holocene climatic events in Granite Harbor, Antarctica, Paleoceanography, 8, 373-386, 1993.

Leventer, A., E. W. Domack, S. Ishman, S. Brachfeld, C. McClennen, and P. Manley, 200-300 year productivity cycles in the Antarctic Peninsula region: Understanding linkages among the Sun, atmosphere, oceans, sea ice and biota, Geol. Soc. Am. Bull, 108, 1626-1644, 1996

Libes, S. M., An Introduction to Marine Biogeochemistry, John Wiley, New York, 1992.

Martin, J. H., S. E. Fitzwater, and R. M. Gordon, Iron deficiency limits plankton growth in Antarctic waters, Global Biogeochem. Cycles, 4, 5-12, 1990.

Massom, R. A., P. T. Harris, K. J. Michael, and M. J. Potter, The distribution and formative processes of latent-heat polynyas in East Antarctica, Ann. Glaciol., 27, 420-426, 1998. 
McManus, J., W. M. Berelson, D. E. Hammond, T. E. Kilgore, D. J. DeMaster, O. Ragueneau, and R. W. Collier, Early diagenesis of biogenic silica: Dissolution rates, kinetics, and paleoceanographic implications, Deep Sea Res., Part II, 42, 871-903, 1995.

McMurtry, G. M., A. Snidvongs, and C. R. Glenn, Modeling sediment accumulation and soil erosion with ${ }^{137} \mathrm{Cs}$ and ${ }^{210} \mathrm{~Pb}$ in the Ala Wai Canal and central Honolulu watershed. Hawai'i, Pac. Sci., 49. 412-451, 1995.

Mortlock, R. A., and P. N. Froelich, A simple method for the rapid determination of biogenic opal in pelagic marine sediments, Deep Sea Res., Part I, 36, 1415-1426, 1989

Mortlock, R. A., C. D. Charles, P N. Froelich, M. A. Zibello, J Saltzmann, J. D. Hays, and L. H. Burckle, Evidence for lower productivity in the Antarctic Ocean dunng the last glaciation, Narure, $351,220-222,1991$.

Nelson, D. M., D. J. DeMaster, R. B. Dunbar, and W. O. Smith, Cyclıng of organic carbon and biogenic silica in the Southern Ocean: Large-scale estimates of water column and sedimentary fluxes in the Ross Sea, J. Geophys. Res., I0I, 18,519. $18,532,1996$.

O'Brien, P. E., E. M. Truswell, and H. Burton, Morphology, seismic stratigraphy and sedimentation history of the Mac Robertson shelf, East Antarctica, Terr. Antarct., 1, 407-408, 1994.

Orsi, A. H., G. C. Johnson, and J. L. Bullister, Circulation, mixing, and production of Antarctic Bottom Water, Prog. Oceanogr., 43, 55-109, 1999.

Parkinson, C. L., Length of the sea ice season in the Southern Ocean, in Antarctic Sea Ice: Physical Processes, Interactions and Variability, Antarct. Res. Ser., vol. 74, edited by M. O. Jeffries, pp. 173-186, AGU, Washington, D. C., 1998.

Popp, B. N. et al., Controls on the carbon isotopic composition of Southern Ocean phytoplankton, Global Biogeochem. Cycles, 13, 827-843, 1999.

Price, N. B., S. E. Calvert, and P. G. W. Jones, The distribution of iodine and bromine in the sediments of the southwestern Barents Sea, J. Mar. Res., 28 , 22-34, 1970.

Rathbum, A. E., J.-J. Pichon, M. A. Ayress, and P. De
Deckker, Microfossil and stable-isotope evidence for changes in late Holocene paleoproductivity and paleoceanographic conditions in the Prydz Bay region of Antarctica, Palaeogeogr. Palaeoclimatol. Palaeoecol., 131, 485-510, 1997.

Rodriguez, A. B., and E. W. Domack, A geochemical sedimentological analysis of glacial marine sediments from the Palmer Deep Basin, Bellingshausen Sea, Antarctica, Antarct. J. U.S. 29, 128-130, 1994

Sakshaug, E., D. Slagstad, and O. Holm-Hansen, Factors controlling the development of phytoplankton blooms in the Antarctic Ocean - A mathernatical model, Mar. Chem., 35, 259-271, 1991.

Samson, C., Structure and timing of the last deglaciation in the subtropical and subpolar southwest Pacific: Implications for driving forces for climate, Ph.D. thesis, Univ. of Tasmania, Hobart, Tasmania, Australia, 1999.

Sedwick, P. N., and G. R. DiTullio, Regulation of algal blooms in Antarctic shelf waters by the release of iron from melting sea ice, Geophys. Res. Lett., 24, 2515-2518, 1997.

Sedwick, P. N., P. T. Harris, L. G. Robertson, G. M. McMurtry, M. D. Cremer, and P. Robinson, A geochemical study of marine sediments from the Mac. Robertson Shelf, East Antarctica: Initial results and palaeonvironmental implications, Ann. Glaciol., 27, 268-274, 1998.

Sedwick, P. N., G. R. DiTullio, and D. J. Mackey, Iron and manganese in the Ross Sea, Antarctica: Seasonal iron limitation in Antarctic shelf waters, $J$. Geophys, Res., 105, 11,321-11,336, 2000.

Shevenell, A. E., E. W. Domack, and G. M. Kernan, Record of Holocene palaeoclimate change along the Antarctic Peninsula: Evidence from glacial marine sediments, Lallemand Fjord, Pap. Proc. $R$. Soc. Tasmania, 130, 55-64, 1996.

Shimmield, G. B., The geochemistry and mineralogy of Pacific sediments, Baja Californı, Ph.D. thesis, Univ. of Edinburgh, Edinburgh, Scotland, 1984.

Sikes, E. L., C. R. Samson, T. P. Guilderson, and W. R. Howard, Old radiocarbon ages in the southwest Pacific Ocean during the last glacial period and deglaciation, Nature, 405, 555-557, 2000.
Smith, N. R., D. Zhaoquian, and S. Wright, Water masses and circulation in the region of Prydz Bay, Antarctica, Deep Sea Res., 31, 1121-1147, 1984.

Smith, W. O., Jr., and L. I. Gordon, Hyperproductivity of the Ross Sea (Antarctica) polynya during austral spring, Geophys. Res. Lett., 24, 233-236, 1997.

Smith, W. O., Jr., and D. M. Nelson, Importance of ice-edge phytoplankton production in the Southern Ocean, BioScience, 36, 251-256, 1986

Smith, W. O.. Jr., and D. M. Nelson, Phytoplankton growth and new production in the Weddell Sea marginal ice zone in the austral spring and autumn. Limnol. Oceanogr., 35, 809-821, 1990.

Smith, W. O., Jr., D. M. Nelson, G. R. DiTullio, and A. R. Leventer, Temporal and spatial patterns in the Ross Sea: Phytoplankton biomass, elemental composition, productivity and growth rates, $J$. Geophys. Res., 101, 18,455-18,465, 1996.

Stuiver, M., and H. A. Polach, Discussion: Reporting of 'C data, Radiocarbon, 19, 355-363, 1977.

Taylor, F., Sedimentary diatom assemblages of Prydz Bay, Ph.D. thesss, Univ. of Tasmania, Hobart, Tasmania, Australia, 1999.

Tréguer, P., and G. Jacques, Dynamics of nutrients and phytoplankton, and fluxes of carbon, nitrogen and silicon in the Antarctic Ocean, Polar Btol., 12, 149-162, 1992.

Wedepohl, K. H., Environmental influences on the chemical composition of shales and clays, Physics and Chemistry of the Earth, edited by L. $\mathrm{H}$. Ahrens, pp. 307-331, Pergamon, Tarrytown, N. Y., 1971.

M. D. Cremer and G. M. McMurtry, Department of Oceanography, University of Hawaii, Honolulu, HI 96822.

P. T. Harris, L. G. Robertson, and P. N. Sedwick. Antarctic CRC, GPO Box 252-80, Hobart, Tasmania 7001, Australia. (P.Sedwick@utas.edu au.)

P. Robinson, Department of Geology, University of Tasmania, GPO Box 252-79, Hobart, Tasmania 7001, Australia.

(Received February 1, 2000;

revised October 15, 2000;

accepted November 27, 2000. 